\section{Endoscopic transnasal orbital decompression for visual failure due to sphenoid wing meningioma}

\begin{abstract}
Aim To review a group of patients with sphenoid wing meningioma and visual impairment. The technique and results for endoscopic transnasal decompression of the orbital apex is presented.

Patients and methods Patients presenting between 1993 and 2004 with visual impairment due to sphenoid wing meningioma were identified. All patients had full ophthalmic assessment, automated visual field testing, and appropriate orbital imaging. Patients with clinical evidence of significant progression in visual impairment (loss of acuity, reduced colour discrimination, or field deterioration) underwent endoscopic transnasal orbital decompression.
\end{abstract}

Outcome measures Assessment of visual function (Snellen acuity, Ishihara colour perception, and visual field testing), together with other measures of orbital structure and function (ocular balance, ductions, and exophthalmometry).

Results Twelve patients (all women) presented to the Orbital Clinic between the ages of 38 and 71years (mean 42.6; median 48.5 years) and with symptoms for an average of 32 months (3-102 months; median 22). The most common symptom was swelling and proptosis, in $11(91 \%)$ patients, and subjective deterioration of vision had been noted in six cases $(50 \%)$. Eight right orbits $(67 \%)$ were affected and the preoperative acuity varied between Snellen 6/5 and counting fingers, with visual field impairment in all cases. There was an average of $5.0 \mathrm{~mm}$ of axial proptosis (range 5-9 mm; median 5 ). Endoscopic decompression was without complication in all cases. With a follow-up interval of 33.9 months (range 5-80; median 26
VJ Lund ${ }^{1}$ and GE Rose ${ }^{2}$

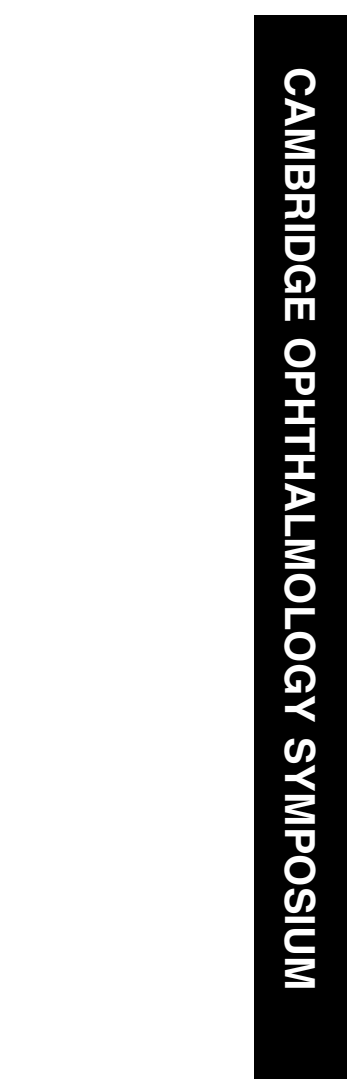

months), there was a subjective and objective improvement in visual functions - with Snellen acuity improving between 1 and 4 lines in seven patients, reduction in relative afferent pupillary defect in 10/12 patients, and improved visual field testing. There was a $2.3 \mathrm{~mm}$ reduction in proptosis (1-4 $\mathrm{mm}$; median $3 \mathrm{~mm}$ ) with less lid swelling, improved ocular balance and motility in four patients, and slightly worse diplopia in one patient. Three patients required further procedures: one had ipsilateral middle meatal antrostomy for retained secretions at $\mathbf{1 8}$ months and two had strabismus surgery. Three patients underwent fractionated radiotherapy for large tumours, or for late tumour growth and recurrent visual impairment.

Conclusion Orbital decompression by transnasal endoscopic ethmoidectomy appears to alleviate optic nerve compression due to sphenoid wing meningioma, with a reasonable relief of the condition for some years. Some patients will require later radiotherapy for progressive tumour growth or visual failure.

Eye (2006) 20, 1213-1219. doi:10.1038/sj.eye.6702385

Keywords: optic neuropathy; orbital decompression; endoscopic surgery; ethmoidectomy

Introduction

Compressive optic neuropathy usually occurs due to tissue crowding in the posterior onethird of the orbit, this most typically being due to the muscular enlargement of thyroid eye disease. ${ }^{1,2}$ Occasionally optic neuropathy results from discrete tumours, such as cavernous haemangiomas, wedged in the orbital apex or
${ }^{1}$ Institute of Laryngology and Otology, London, UK

${ }^{2}$ Orbital Service, Moorfields Eye Hospital, London, UK

Correspondence: GE Rose, Orbital Service, Moorfields Eye Hospital, City Road, London EC1V 2PD, UK Tel: + 44207566 203; Fax: + 442075662019 . E-mail: geoff.rose@ moorfields.nhs.uk

Received: 12 March 2006 Accepted: 22 March 2006 
from abnormalities of the orbital wall causing optic nerve compression. Apart from trauma, sphenoidal wing meningioma is the most common orbital wall abnormality and this tumour usually expands into the orbit, temporalis fossa, and middle cranial fossa; more rarely, bone expansion is due to fibro-osseous disease or metastatic tumour.

Surgical relief of thyroid optic neuropathy has been practised for many years, ${ }^{3,4}$ this requiring bone removal and opening of the apical orbital periosteum - thereby relieving high tissue pressures in the orbital apex. ${ }^{1-4}$ As the medial orbital wall is very thin and extends in continuity to the apex, it is the most readily removed for this purpose. The orbital floor is removable only to the back of the maxilla, about $1 \mathrm{~cm}$ short of the orbital apex, and although the lateral wall (greater wing of the sphenoid) can be burred away to the apex, this tends to be an awkward procedure - with thick bone and bleeding from the vascular diploi. Many different approaches to orbital decompression have been described ${ }^{3,4}$ but there has been recent interest in approaches that avoid skin incision-for example, the transcaruncular approach to the medial orbital wall. 5,6 Intraoral (transantral) or transnasal decompression has been used for many years to remove the medial orbital wall and part of the floor, and is well described in patients with thyroid eye disease. ${ }^{78}$

Rarely, orbital decompression has also been used to relieve optic neuropathy, secondary to disorders of cranial bone such as fibrous dysplasia, ${ }^{9,10}$ osteopetrosis, ${ }^{11}$ or renal osteodystrophy. ${ }^{12}$ While transnasal and/or transorbital approaches have been described for optic canal decompression in patients with post-traumatic optic neuropathy, ${ }^{13-17}$ the efficacy of this procedure remains very doubtful. ${ }^{18}$

We present a series of patients with optic neuropathy, secondary to orbital encroachment by the sphenoidal wing meningioma, treated by transnasal endoscopic medial orbital decompression.

\section{Patients and methods}

A retrospective review of clinical records was undertaken for patients presenting between 1990 and 2004 with visual impairment due to sphenoid wing meningioma, the patients being identified from the Orbital Clinic database at Moorfields Eye Hospital. All patients had full ophthalmic assessment, automated visual field testing, and appropriate orbital imaging. Patients with clinical evidence of significant progression in visual impairment (loss of acuity, reduced colour discrimination, or field deterioration) underwent endoscopic transnasal orbital decompression and the visual and structural outcome for this procedure was reviewed.
Where there was significant continued progression of visual failure, patients were referred for external beam radiotherapy to a total dosage of about 4500 cGy (fractioned to 200 cGy daily).

\section{Surgical technique}

The procedure was performed under general anaesthesia, with moderate hypotension (typically $90 / 60 \mathrm{mmHg}$ ), and the patient positioned in a reverse Trendelenberg position. After anaesthesia, the nasal space was packed with gauze soaked in Moffatt's solution ( $2 \mathrm{ml}$ of $10 \%$ cocaine solution, $1 \mathrm{ml}$ of $1: 1000$ epinephrine, and $2 \mathrm{ml}$ of $2 \%$ sodium bicarbonate) and the intranasal nasal haemostasis supplemented during surgery by use of topical 1:1000 epinephrine applied on a ribbon gauze.

In the absence of prior sinus surgery, a routine endoscopic dissection ${ }^{7}$ was undertaken to expose the entire medial wall of the ethmoid labyrinth - this including uncinectomy, clearance of the bulla, perforation of the basal lamella of the middle turbinate, and opening widely into the posterior ethmoids. The sphenoid ostium was identified in the sphenoethmoidal recess and enlarged, often with reduction of some middle and superior turbinate, and the opening extended laterally into the posterior ethmoid, to define the junction of the posterior ethmoid and sphenoid. Dependent upon the extent of meningioma within the orbit, the lamina papyracea was removed up to this junction using an elevator and Blakesley-Wilde forceps. The bone is thicker behind the junction and, before manual removal, often needs thinning with an irrigated sheathed endoscopic drill. Using drills, elevators, and curettes specifically designed for this purpose, the dissection was continued along the lateral wall of the sphenoid to a variable degree, dependent on the extent of the pathology and local anatomy - for example, the presence of sphenoethmoidal pneumatisation. Some bleeding from the bone may be encountered due to alteration of local blood supply and/or microscopic infiltration by meningioma but can be managed by application of topical epinephrine. Resected bone is submitted for histology and may confirm the diagnosis of meningioma.

The orbital periosteum was opened widely with a disposable sickle knife, the opening including the Annulus of Zinn and extending anteriorly; the extent of anterior incision being as with conventional orbital decompression, releasing the orbital fat and medial rectus into the surgical cavity. Within the canal, the incision should be shallow and in the superomedial quadrant to avoid damage to the inferiorly positioned ophthalmic artery. In theory, opening of the optic nerve sheath should result in cerebrospinal fluid leak, but this is not seen in practice - although tiny pledgets of gelatin 
sponge soaked in Sofradex (Florizel Ltd, Stevenage, UK) are applied locally as a prophylaxis against infection. A small telfa packet is inserted for up to $24 \mathrm{~h}$, dependent on haemostasis.

The patient was discharged, after removal of nasal packing on the first postoperative day, and advised to avoid nose blowing for $72 \mathrm{~h}$. An alkaline nasal douche, topical steroid spray, and oral erythromycin (500 mg twice-daily) were prescribed for the first 10-14 days after surgery. Endoscopic cleaning of the cavity was performed, as an outpatient, at about 2 weeks after surgery and long-term ophthalmic review arranged.

\section{Results}

\section{Case reports}

Case 1 (patient 11)

A 52-year-old white woman was referred to the Orbital Clinic with a 4-month history of painless swelling of the right eyelids. Her visual acuity was Snellen 6/5, with full Ishihara colour perception and no relative afferent pupillary defect (RAPD); the right visual field test showed a mild, patchy loss of sensitivity (Figure 1a). There was $3 \mathrm{~mm}$ right relative proptosis, eye movements were normal, and there was mild swelling of the right optic disc. CT scan demonstrated features of sphenoidal wing meningioma with hyperostosis and a soft-tissue component within the orbit (Figure 2).

After 2 years, there was evidence of clinical progression: the acuity decreased to $6 / 9$, there was mild impairment of Ishihara colour testing, a moderate RAPD, severe impairment of visual field function (Figure 1b), and $7 \mathrm{~mm}$ right relative proptosis.

The patient underwent right transnasal endoscopic ethmoidectomy at 3 years after the start of symptoms, with restoration of the acuity to $6 / 5$, normal Ishihara testing, a reduction in the right RAPD, and exophthalmos reduced to $4 \mathrm{~mm}$. Visual field tests showed marked
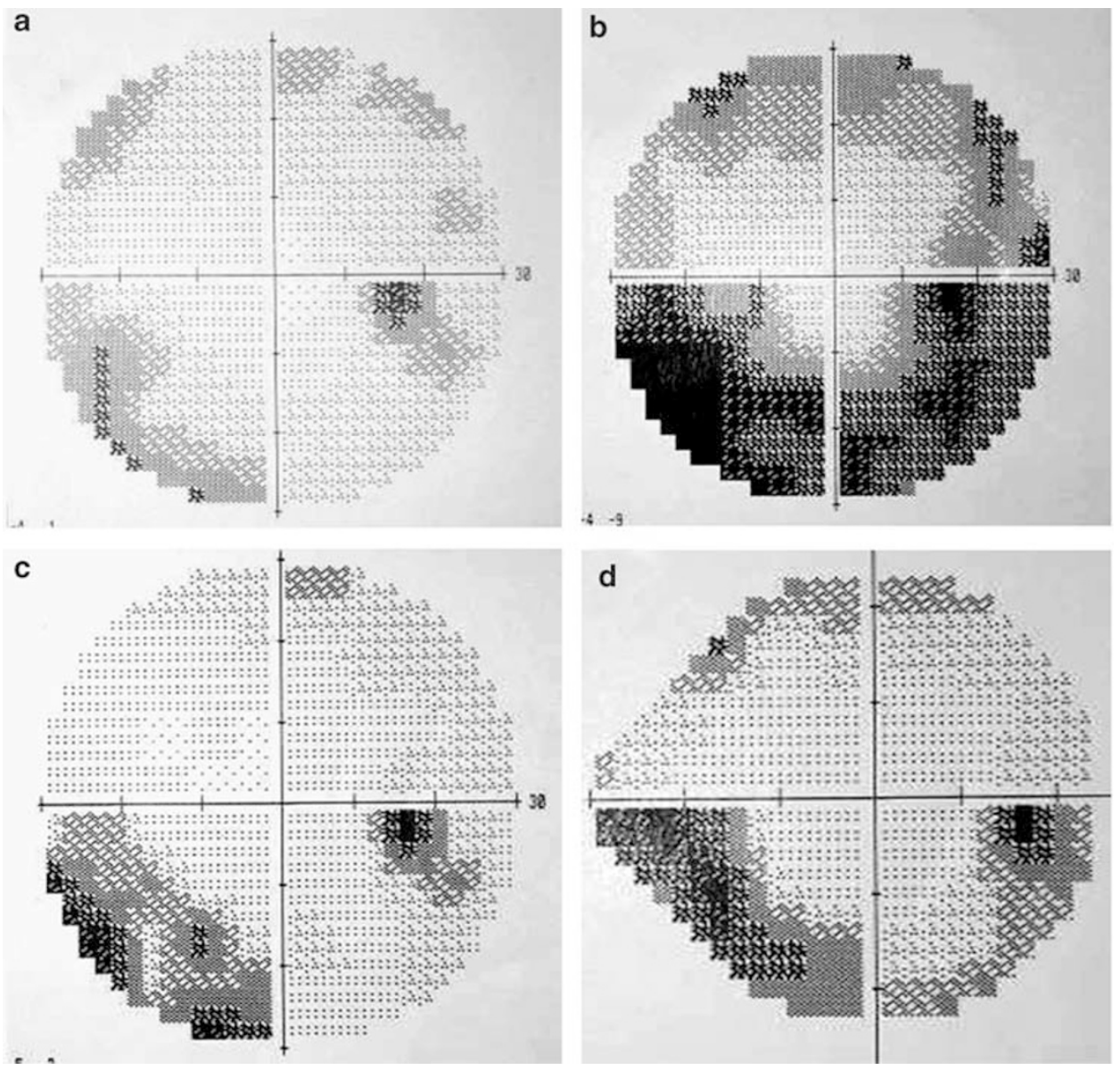

Figure 1 (Patient 11) Serial visual field testing for the right eye of a 52-year-old woman presenting with painless unilateral impairment of visual function and eyelid swelling due to right sphenoid wing meningioma. Right visual field testing (a) at presentation, (b) 2 years later, and after observation only. (c) Transnasal endoscopic medial orbital decompression at 3 years after presentation resulted in improved visual field functions, and (d) the mild residual impairment showing only minimal progression by 4 years after decompression (7 years after initial presentation). 
improvement (Figure 1c). At 4 years after decompression, the right visual acuity was 6/9 with a mild right RAPD, mild impairment of Ishihara colour perception, and a

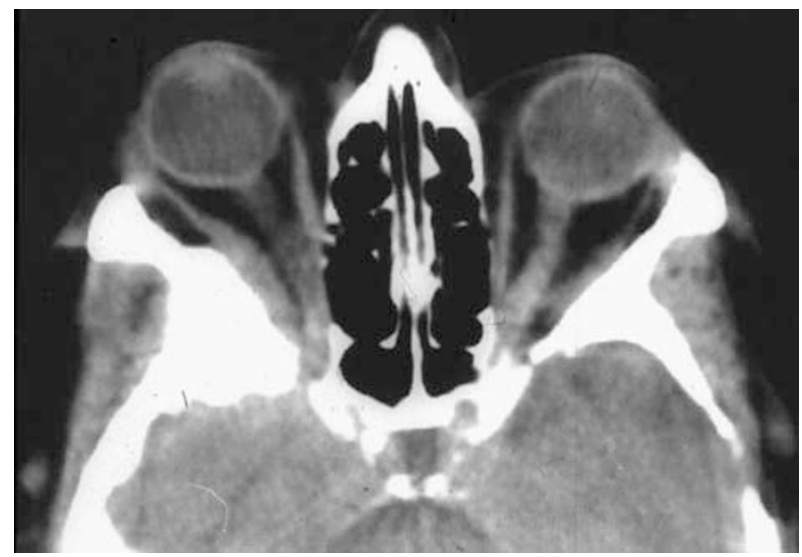

Figure 2 (Patient 11) Orbital CT scan at presentation, showing the typical appearance of right sphenoid wing meningioma.
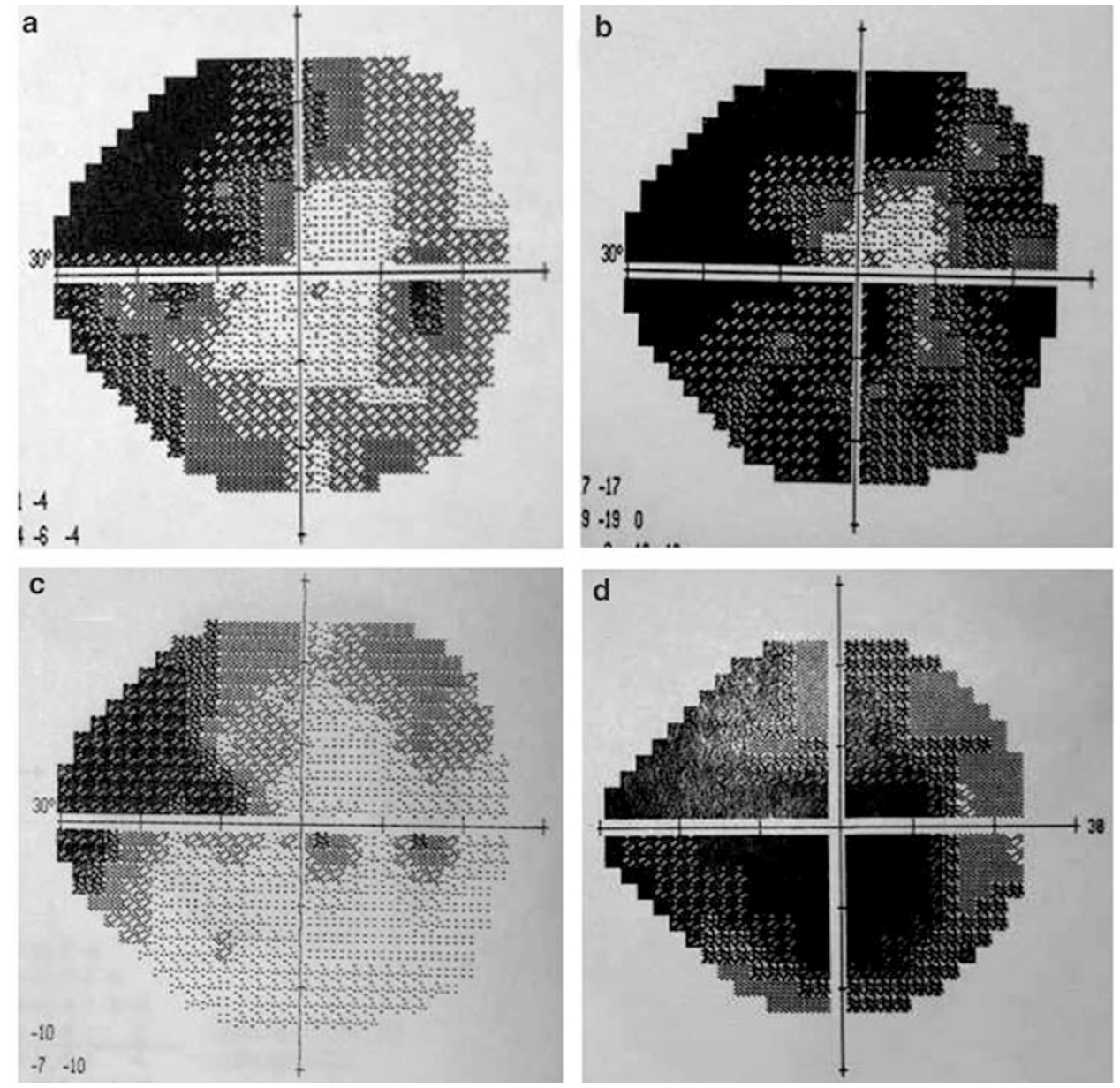

Figure 3 (Patient 8) Serial visual field tests for the right eye of a 40-year-old woman with bilateral chronic open-angle glaucoma and right sphenoid wing meningioma; the fields showing progression of loss ( $a$ and $b$ ) in the face of adequate control of intraocular pressure. (c) Transnasal endoscopic medial orbital decompression resulted in an improvement of the visual field. External beam radiotherapy was administered 3 years later because of deteriorating acuity, colour perception, and progression of the right field defect - with stabilisation of the impaired visual field function $(\mathrm{d})$. mild field defect (Figure 1d). There was $6 \mathrm{~mm}$ right relative proptosis and persistent mild swelling of the optic disc.

\section{Case 2 (patient 8)}

A 40-year-old West Indian woman with known chronic open-angle glaucoma on topical medication was referred with a 14-month history of painless right proptosis and failing vision. Her right acuity had deteriorated from Snellen $6 / 9$ to $6 / 24$, with a dense right RAPD, no Ishihara colour perception, and a progressive visual field defect (Figures 3a and b) with some optic atrophy. Orbital CT was characteristic of sphenoidal wing meningioma.

A right medial orbital decompression was performed, with a marked improvement in vision to $6 / 5$, resolution of the right RAPD, and improved right visual field (Figure 3c). There was a $2 \mathrm{~mm}$ reduction in the degree of right exophthalmos.

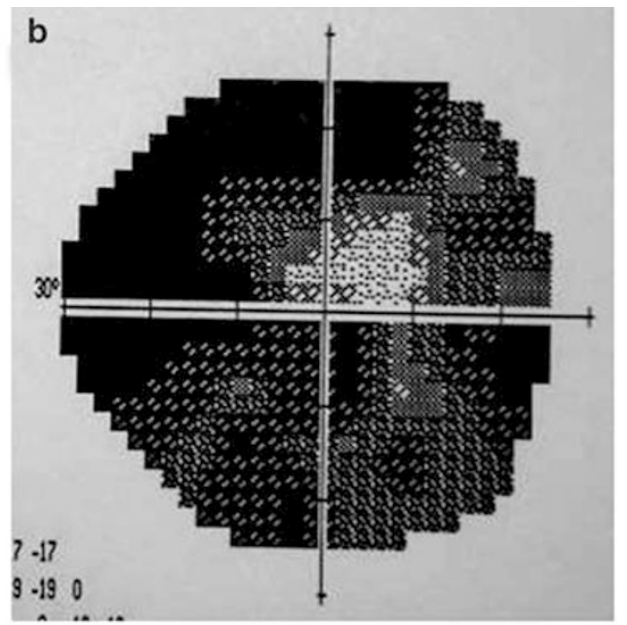


After 3 years, there was evidence of recurrent optic neuropathy - with reduced acuity (to 6/9), failing colour perception, a moderate RAPD and a deteriorating visual field. The patient underwent $5000 \mathrm{cGy}$ external beam radiotherapy, fractionated in 200 cGy doses over 42 days, with clinical signs stable over a follow-up interval of nearly 5 years; the visual field in her affected right eye remained impaired (Figure 1d), with diffuse optic atrophy.

\section{Group characteristics}

Twelve patients, all women, were referred to the Orbital Clinic between the ages of 38 and 71 years (mean 42.6; median 48.5 years), with symptoms for an average of 32 months (3-102 months; median 22) (Table 1). The most common symptom was swelling or proptosis, occurring in $11 / 12(91 \%)$ patients, and subjective deterioration of vision had been noted in six cases $(50 \%)$. Pain, typically variable headache, was present in two patients and the right orbit was affected in eight $(67 \%)$.

Preoperative acuity varied between Snellen 6/5 and counting fingers, with visual field impairment in all cases, and there was an average of $5.0 \mathrm{~mm}$ of axial proptosis relative to the normal side $(5-9 \mathrm{~mm}$; median $5 \mathrm{~mm}$ ). A minor impairment of ocular ductions was present in some (8/12) patients (Table 2). Endoscopic decompression was achieved without complication in all cases, and specimens taken at surgery confirmed the radiological diagnosis. With a follow-up of 33.9 months (5-80 months; median 26), there was a subjective and objective improvement in visual functions - with an

Table 1 Clinical characteristics for 12 women at presentation with sphenoid wing meningioma and visual impairment

\begin{tabular}{|c|c|c|c|c|c|}
\hline $\begin{array}{l}\text { Patient } \\
\text { number }\end{array}$ & $\begin{array}{c}\text { Age at } \\
\text { presentation }\end{array}$ & $\begin{array}{l}\text { Symptoms on presentation; } \\
\text { duration (months) }\end{array}$ & $\begin{array}{l}\text { Visual functions on } \\
\text { presentation }\end{array}$ & $\begin{array}{l}\text { Other signs on } \\
\text { presentation }\end{array}$ & $\begin{array}{l}\text { Reason for decompression; } \\
\text { months after presentation }\end{array}$ \\
\hline 1 & 49 & Left proptosis; 3 & $\begin{array}{l}\text { Acuity } 6 / 9 \text {; no RAPD } \\
\text { Full Ishihara testing } \\
\text { Severe field defect }\end{array}$ & $\begin{array}{l}5 \mathrm{~mm} \text { proptosis } \\
\text { Moderate EOM restriction } \\
\text { Optic disc swelling }\end{array}$ & Loss visual field; 3 \\
\hline 2 & 42 & $\begin{array}{l}\text { Right proptosis, } \\
\text { headache, diplopia; } 8\end{array}$ & $\begin{array}{l}\text { Acuity } 6 / 9 ; \text { moderate } \\
\text { RAPD } \\
\text { Full Ishihara testing }\end{array}$ & $\begin{array}{l}4 \mathrm{~mm} \text { proptosis } \\
\text { Moderate EOM restriction } \\
\text { Normal optic disc }\end{array}$ & Decreasing acuity; 37 \\
\hline 3 & 48 & $\begin{array}{l}\text { Right proptosis, } \\
\text { decreased vision; } 102\end{array}$ & $\begin{array}{l}\text { Acuity } 6 / 9 ; \text { moderate } \\
\text { RAPD } \\
\text { Poor Ishihara testing } \\
\text { Moderate field defect }\end{array}$ & $\begin{array}{l}8 \mathrm{~mm} \text { proptosis } \\
\text { Moderate EOM restriction } \\
\text { Optic atrophy }\end{array}$ & $\begin{array}{l}\text { Poor colour perception } \\
\text { and proptosis; } 2\end{array}$ \\
\hline 4 & 38 & Right proptosis; 31 & $\begin{array}{l}\text { Acuity } 6 / 5 \text {; no RAPD } \\
\text { Fair Ishihara testing }\end{array}$ & $\begin{array}{l}2 \mathrm{~mm} \text { proptosis } \\
\text { Normal EOM } \\
\text { Optic atrophy }\end{array}$ & Increasing proptosis; 53 \\
\hline 5 & 71 & $\begin{array}{l}\text { Right proptosis, } \\
\text { decreased vision, } \\
\text { diplopia; } 55\end{array}$ & $\begin{array}{l}\text { Acuity } 6 / 6 \text {; no RAPD } \\
\text { Full Ishihara testing }\end{array}$ & $\begin{array}{l}7 \mathrm{~mm} \text { proptosis } \\
\text { Mild EOM restriction } \\
\text { Normal optic disc }\end{array}$ & $\begin{array}{l}\text { Markedly } \\
\text { decreasing acuity } \\
\text { and proptosis; } 90\end{array}$ \\
\hline 6 & 48 & Right proptosis; 49 & $\begin{array}{l}\text { Acuity } 6 / 9 \text {; mild RAPD } \\
\text { Fair Ishihara testing }\end{array}$ & $\begin{array}{l}7 \mathrm{~mm} \text { proptosis } \\
\text { Normal EOM } \\
\text { Normal optic disc }\end{array}$ & $\begin{array}{l}\text { Visual impairment } \\
\text { and proptosis; } 4\end{array}$ \\
\hline 7 & 54 & $\begin{array}{l}\text { Left proptosis, } \\
\text { decreased vision; } 73\end{array}$ & $\begin{array}{l}\text { Acuity } 6 / 9 \text {; mild RAPD } \\
\text { Fair Ishihara testing } \\
\text { Severe field defect }\end{array}$ & $\begin{array}{l}5 \mathrm{~mm} \text { proptosis } \\
\text { Normal EOM } \\
\text { Optic atrophy }\end{array}$ & $\begin{array}{l}\text { Visual impairment } \\
\text { and proptosis; } 4\end{array}$ \\
\hline 8 & 40 & $\begin{array}{l}\text { Right proptosis, } \\
\text { decreased vision; } 13\end{array}$ & $\begin{array}{l}\text { Acuity 6/24; marked RAPD } \\
\text { (No Ishihara test-plate) } \\
\text { Severe field defect }\end{array}$ & $\begin{array}{l}6 \mathrm{~mm} \text { proptosis } \\
\text { Mild EOM restriction } \\
\text { Optic atrophy }\end{array}$ & $\begin{array}{l}\text { Marked visual } \\
\text { impairment } \\
\text { and proptosis; } 2\end{array}$ \\
\hline 9 & 55 & $\begin{array}{l}\text { Right proptosis, } \\
\text { decreased vision, } \\
\text { diplopia; } 18\end{array}$ & $\begin{array}{l}\text { Acuity 6/6; moderate RAPD } \\
\text { Fair Ishihara testing }\end{array}$ & $\begin{array}{l}5 \mathrm{~mm} \text { proptosis } \\
\text { Mild EOM restriction } \\
\text { Optic disc swelling }\end{array}$ & $\begin{array}{l}\text { Decreasing } \\
\text { acuity; } 3\end{array}$ \\
\hline 10 & 55 & $\begin{array}{l}\text { Left decreased } \\
\text { vision; } 4\end{array}$ & $\begin{array}{l}\text { Acuity } 6 / 9 ; \text { mild RAPD } \\
\text { Fair Ishihara testing } \\
\text { Moderate field defect }\end{array}$ & $\begin{array}{l}5 \mathrm{~mm} \text { proptosis } \\
\text { Moderate EOM restriction } \\
\text { Optic atrophy }\end{array}$ & $\begin{array}{l}\text { Loss visual } \\
\text { field; } 16\end{array}$ \\
\hline 11 & 52 & Right proptosis; 4 & $\begin{array}{l}\text { Acuity } 6 / 5 \text {; no RAPD } \\
\text { Full Ishihara testing } \\
\text { Mild field defect }\end{array}$ & $\begin{array}{l}3 \mathrm{~mm} \text { proptosis } \\
\text { Normal EOM } \\
\text { Optic disc swelling }\end{array}$ & $\begin{array}{l}\text { Loss visual field } \\
\text { and proptosis; } 32\end{array}$ \\
\hline 12 & 44 & $\begin{array}{l}\text { Left proptosis, } \\
\text { headache; } \\
\text { diplopia; } 25\end{array}$ & $\begin{array}{l}\text { Acuity 6/6; marked } \\
\text { RAPD } \\
\text { Fair Ishihara testing }\end{array}$ & $\begin{array}{l}5 \mathrm{~mm} \text { proptosis } \\
\text { Mild EOM restriction } \\
\text { Optic disc swelling }\end{array}$ & $\begin{array}{l}\text { Increasing RAPD } \\
\text { and proptosis; } 5\end{array}$ \\
\hline
\end{tabular}


Table 2 Clinical characteristics just prior to and after, orbital decompression

\begin{tabular}{|c|c|c|c|c|c|}
\hline $\begin{array}{l}\text { Patient } \\
\text { number }\end{array}$ & $\begin{array}{l}\text { Visual functions } \\
\text { before decompression }\end{array}$ & $\begin{array}{l}\text { Other signs before } \\
\text { decompression }\end{array}$ & $\begin{array}{l}\text { Early postoperative } \\
\text { clinical signs }\end{array}$ & $\begin{array}{l}\text { Follow-up after decompression } \\
\text { and late clinical signs }\end{array}$ & $\begin{array}{l}\text { Further treatments; time } \\
\text { (months) after decompression }\end{array}$ \\
\hline \multirow[t]{3}{*}{1} & Acuity $6 / 9 ;$ no RAPD & $5 \mathrm{~mm}$ proptosis & Acuity 6/6; no RAPD & 5 months & - \\
\hline & Full Ishihara testing & Moderate EOM restriction & Full Ishihara testing & Acuity 6/6; no RAPD & - \\
\hline & Marked field defect & Optic disc swelling & $4 \mathrm{~mm}$ proptosis & $3 \mathrm{~mm}$ proptosis & - \\
\hline \multirow[t]{3}{*}{2} & Acuity $6 / 12$; moderate RAPD & $5 \mathrm{~mm}$ proptosis & Acuity $6 / 12$; mild RAPD & 66 months & Radiotherapy; 15 \\
\hline & (Ishihara test-plate only) & Moderate EOM restriction & (Ishihara test-plate only) & Acuity $<6 / 60$; marked RAPD & - \\
\hline & & Optic atrophy & $4 \mathrm{~mm}$ proptosis & $4 \mathrm{~mm}$ proptosis & - \\
\hline \multirow[t]{3}{*}{3} & Acuity $6 / 9$; moderate RAPD & $8 \mathrm{~mm}$ proptosis & Acuity 6/9; mild RAPD & 11 months & - \\
\hline & Poor Ishihara testing & Moderate EOM restriction & Poor Ishihara testing & Acuity 6/6; mild RAPD & Radiotherapy; 1 \\
\hline & Moderate field defect & Optic atrophy & $6 \mathrm{~mm}$ proptosis & $6 \mathrm{~mm}$ proptosis & Strabismus surgery; 9 \\
\hline \multirow[t]{3}{*}{4} & Acuity 6/5; mild RAPD & $9 \mathrm{~mm}$ proptosis & Acuity 6/5; mild RAPD & 80 months & - \\
\hline & Fair Ishihara testing & Normal EOM & Fair Ishihara testing & Acuity 6/6; no RAPD & - \\
\hline & & Optic atrophy and swelling & $6 \mathrm{~mm}$ proptosis & $3 \mathrm{~mm}$ proptosis & - \\
\hline \multirow[t]{3}{*}{5} & Acuity <6/60; marked RAPD & $9 \mathrm{~mm}$ proptosis & Acuity 6/18; moderate RAPD & 23 months & - \\
\hline & (Ishihara test-plate only) & Moderate EOM restriction & (poor Ishihara testing) & Acuity 6/12; mild RAPD & - \\
\hline & & Optic disc swelling & $8 \mathrm{~mm}$ proptosis & $5 \mathrm{~mm}$ proptosis & - \\
\hline \multirow[t]{3}{*}{6} & Acuity 6/9; mild RAPD & $7 \mathrm{~mm}$ proptosis & Acuity 6/6; mild RAPD & 42 months & - \\
\hline & Fair Ishihara testing & Normal EOM & Full Ishihara testing & Acuity 6/9; mild RAPD & - \\
\hline & & Normal optic disc & $5 \mathrm{~mm}$ proptosis & $7 \mathrm{~mm}$ proptosis & - \\
\hline \multirow[t]{3}{*}{7} & Acuity 6/9; mild RAPD & $5 \mathrm{~mm}$ proptosis & Acuity 6/9; no RAPD & 25 months & Strabismus surgery; 6 \\
\hline & Fair Ishihara testing & Normal EOM & Fair Ishihara testing & Acuity 6/9; mild RAPD & - \\
\hline & Marked field defect & Optic atrophy & $2 \mathrm{~mm}$ proptosis & $3 \mathrm{~mm}$ proptosis & - \\
\hline \multirow[t]{3}{*}{8} & Acuity 6/24; marked RAPD & $6 \mathrm{~mm}$ proptosis & Acuity 6/6; no RAPD & 63 months & Radiotherapy; 41 \\
\hline & (no Ishihara test-plate) & Mild EOM restriction & Fair Ishihara testing & Acuity 6/24; moderate RAPD & - \\
\hline & Marked field defect & Optic atrophy & $5 \mathrm{~mm}$ proptosis & $6 \mathrm{~mm}$ proptosis & - \\
\hline \multirow[t]{3}{*}{9} & Acuity $6 / 9$; moderate RAPD & $5 \mathrm{~mm}$ proptosis & Acuity 6/6; mild RAPD & 12 months & - \\
\hline & Fair Ishihara testing & Mild EOM restriction & Full Ishihara testing & Acuity 6/5; mild RAPD & - \\
\hline & & Optic disc swelling & $3 \mathrm{~mm}$ proptosis & $1 \mathrm{~mm}$ proptosis & - \\
\hline \multirow[t]{3}{*}{10} & Acuity $6 / 9$; moderate RAPD & $5 \mathrm{~mm}$ proptosis & Acuity 6/6; mild RAPD & 8 months & - \\
\hline & Fair Ishihara testing & Moderate EOM restriction & Fair Ishihara testing & Acuity 6/6; no RAPD & - \\
\hline & Marked field defect & Optic atrophy & $2 \mathrm{~mm}$ proptosis & $2 \mathrm{~mm}$ proptosis & - \\
\hline \multirow[t]{3}{*}{11} & Acuity $6 / 6$; moderate RAPD & $7 \mathrm{~mm}$ proptosis & Acuity 6/5; mild RAPD & 45 months & - \\
\hline & Fair Ishihara testing & Normal EOM & Full Ishihara testing & Acuity 6/9; mild RAPD & - \\
\hline & Marked field defect & Optic disc swelling & $4 \mathrm{~mm}$ proptosis & $6 \mathrm{~mm}$ proptosis & - \\
\hline \multirow[t]{3}{*}{12} & Acuity 6/9; marked RAPD & $7 \mathrm{~mm}$ proptosis & Acuity 6/9; mild RAPD & 28 months & Middle meatal antrostomy; 18 \\
\hline & Fair Ishihara testing & Mild EOM restriction & Fair Ishihara testing & Acuity 6/12; mild RAPD & - \\
\hline & Moderate field defect & Optic disc swelling & $3 \mathrm{~mm}$ proptosis & $3 \mathrm{~mm}$ proptosis & - \\
\hline
\end{tabular}

proptosis

Optic atrophy

Mild EOM restriction

disc swelling

$\mathrm{mm}$ proptosis

Optic atrophy

Optic disc swelling

Mild EOM restriction

Moderate field defect 
improvement of Snellen acuity between 1 and 4 lines in seven $(58 \%)$ patients, an improvement in the density of RAPD in 10/12 patients, and, where performed, improvement in visual fields. There was a $2.3 \mathrm{~mm}$ average reduction in proptosis (1-4 mm; median 3$)$, with less swelling of the eyelids (Table 2). In four patients, there was an improvement in ocular balance and motility and slight worsening of diplopia in one patient.

Three patients required further procedures: one (Case 12) had ipsilateral middle meatal antrostomy for retained secretions at 18 months after endoscopic decompression and two (Cases 4 and 7) had strabismus surgery. One patient (Case 4) underwent early planned radiotherapy for a rapidly growing meningioma and two other patients (Cases 2 and 8) had radiotherapy for late tumour growth and recurrent visual impairment - the radiotherapy being at 15 and 41 months after the decompression (Table 2).

\section{Discussion}

The advent of endoscopic sinus surgery has facilitated a direct endonasal approach to the entire medial orbital wall and this, combined with improved imaging (particularly detailed coronal and axial CT scanning) has allowed a precise determination of the local anatomy and underlying pathology. Surgical decompression of the orbital apex has been described in a number of conditions associated with bony and soft-tissue compression, including fibrous dysplasia, ${ }^{9,10}$ osteopetrosis, ${ }^{11}$ and renal osteodystrophy. ${ }^{12}$

Meningiomas of the skull base and orbit compress the orbital apex by a combination of intraorbital tumour and also local hyperostosis of adjacent bone, these changes typically affecting the lateral wall - this enabling a medial decompression to be performed without significantly disturbing the tumour mass. Even when appearing normal on CT, however, the bone of the medial orbital wall is generally infiltrated with meningioma and somewhat more vascular than normal; this conveniently allowing histological confirmation of the presumed diagnosis, using the tissue taken at surgery.

As the patients in our series were mainly affected by visual failure or orbital symptoms, major neurosurgical extirpation of the tumour was considered inappropriate. Although transnasal medial orbital decompression clearly does not cure the underlying disease, it would appear to provide both relief of optic neuropathy and a moderate reduction in proptosis and eyelid swelling - this effect, in most cases, lasting for several years. The extent of the dissection into the lateral wall of the sphenoid is unknown and clearly most decompression occurs within the closed compartment of the orbital apex, close to the optic canal. The decompression - with a very low risk of blindness due to surgery - does not prevent later treatment with radiotherapy or, indeed, the possibility of later neurosurgical resection of the tumour.

\section{References}

1 Kennerdell JS, Rosenbaum AE, El-Hoshy MH. Apical optic nerve compression of dysthyroid optic neuropathy on computed tomography. Arch Ophthalmol 198; 99: 807-809.

2 Neigel JM, Rootman J, Belkin RI, Nugent RA, Drance SM, Beattie CW et al. Dysthyroid optic neuropathy, the crowded orbital apex syndrome. Ophthalmology 1988; 95: 1515-1521.

3 Lucarelli MJ, Shore JW. Management of thyroid optic neuropathy. Int Ophthalmol Clin 1996; 36: 179-193.

4 Siracuse-Lee DE, Kazim M. Orbital decompression: current concepts. Curr Opin Ophthalmol 2002; 13: 310-316.

5 Perry JD, Kadakia A, Foster JA. Transcaruncular orbital decompression for dysthyroid optic neuropathy. Ophthalmic Plast Reconstr Surg 2003; 19: 353-358.

6 Chang EL, Bernardino CR, Rubin PAD. Transcaruncular orbital decompression for management of compressive optic neuropathy in thyroid-related orbitopathy. Plast Reconstr Surg 2003; 112: 739-747.

7 Lund VJ, Larkin G, Fells P, Adams G. Endoscopic orbital decompression. J Laryngol Otol 1997; 111: 1051-1055.

8 Soares-Welch CV, Fatourechi V, Bartley GB, Beatty CW, Gorman CA, Bahn RS et al. Optic neuropathy of Graves disease: results of transantral orbital decompression and long-term follow-up in 215 patients. Am J Ophthalmol 2003; 136: 433-441.

9 Papay FA, Morales L, Flaherty P, Smith SJ, Anderson R, Walker JM et al. Optic nerve decompression in cranial base fibrous dysplasia. J Craniofac Surg 1995; 6: 5-10.

10 Chen YR, Breidahl A, Chang AN. Optic nerve decompression in fibrous dysplasia; indications, efficacy, and safety. Plast Reconstr Surg 1997; 99: 22-30.

11 Hwang JM, Kim IO, Wang KC. Complete visual recovery in osteopetrosis by early optic nerve decompression. Pediatr Neurosurg 2000; 33: 328-332.

12 Schmidt RH, Rietz LA, Patel BC, Osborne AG, Pratt D, Digre KB. Compressive optic neuropathy caused by renal osteodystrophy. Case report. Neurosurgery 2001; 95: 704-709.

13 Maurer J, Hinni M, Mann W, Pfeiffer N. Optic nerve decompression in trauma and tumor patients. Eur Arch Otorhinolaryngol 1999; 256: 341-345.

14 Kountakis SE, Maillard AA, El-Harazi SM, Longhini L, Urso RG. Endoscopic optic nerve decompression for traumatic blindness. Otolaryngol Head Neck Surg 2000; 123: 34-37.

15 Goldberg RA, Steinsapir KD. Extracranial optic canal decompression: indications and technique. Ophthalmic Plast Reconstr Surg 1996; 12: 163-170.

16 Kupersmith RB, Alford EL, Patrinely JR, Lee AG, Parke RB, Holds JB. Combined transconjunctival/intranasal endoscopic approach to the optic canal in traumatic optic neuropathy. Laryngoscope 1997; 107: 311-315.

17 Li KK, Teknos, TN, Lai A, Lauretano A, Terrell J, Joseph MP. Extracranial optic nerve decompression: a 10-year review of 92 patients. J Craniofac Surg 1999; 10: 454-459.

18 Levin LA, Beck RW, Joseph MP, Seiff S, Kraker R. The International Optic Nerve Trauma Study Group. Ophthalmology 1999; 106: 1268-1277. 